\title{
Quantifying Vertical Hyporheic Exchange and hyporheic residence time in thalweg paths of meandering streams characterized by multiple riffle-pool sequences morphology
}

Aminreza Meghdadi $^{1 *}$, Morteza Eyvazi $^{2}$, Zohre Najatijahromi $^{3}$, Bahram Saghafian $^{4}$

$5 \quad{ }^{1}$ PAYARAH Consultant Engineering Company, Department of Research and Engineering, Zanjan, Iran. Email: Meghdadi.aminreza@gmail.com ("Corresponding Author)

${ }^{2}$ Department of Agriculture and Plant Breeding, Faculty of Agriculture, Zanjan University, Zanjan, Iran. Email: $\underline{\text { m.eyvazi@znu.ac.ir }}$

${ }^{3}$ Faculty of Earth Sciences, Department of Minerals and Hydrogeology, Shahid Beheshti

${ }^{4}$ Civil Engineering Department, Islamic Azad University, Science and Research Branch, Tehran, Iran. Email: b.saghafian@srbiau.ac.ir

\begin{abstract}
Riffle-pool sequences in the thalweg paths of meandering streams are of pivotal importance to the hyporheic exchange pattern in a fluvial network, but the complex hydrodynamic, morphological, and sedimentary features of riverbed sediments increase the difficulties associated with vertical hyporheic exchange (VHE) quantification. This study applied depthdependent radon $\left({ }^{222} \mathrm{Rn}\right)$ and diel temperature variations to quantify VHE and residence time $\left(t_{r}\right)$. The study was conducted in four different hyporheic areas with riffle-pool sequences in the third-order Ghezel-Ozan River, located in north-west Iran. The mean values of temperaturederived $\mathrm{VHE}\left(\mathrm{VHE}_{\mathrm{T}}\right)$ and radon-derived $\mathrm{VHE}\left(\mathrm{VHE}_{\mathrm{Rn}}\right)$ were $0.67 \pm 0.32 \mathrm{~m} /$ day and $0.63 \pm 0.36$ $\mathrm{m} /$ day, respectively. Due to effects of sediment bed heterogeneity on temperature variation and ${ }^{222} \mathrm{Rn}$ activity at downwelling and upwelling points, there were discrepancies between radon-
\end{abstract}


derived $\left(\operatorname{tr}_{\mathrm{Rn}}\right)$ and temperature-derived residence time $\left(\operatorname{tr}_{\mathrm{T}}\right)$, with mean values of $2.11 \pm 1.17$ days and $1.87 \pm 1.26$ days, respectively. The value of $\operatorname{tr}_{\mathrm{T}}$ was well within uncertainty boundaries at a 95 percent confidence interval $(\mathrm{p}<0.05)$ and was lower than $\operatorname{tr}_{R n}$ at the downwelling points. The analysis of vertical diel temperature, radon and electrical conductivity variations revealed subsurface water exchange to be greatly affected by larger scale regional flow. The comparison between $\mathrm{VHE}_{\mathrm{T}}$ and $\mathrm{VHE}_{\mathrm{Rn}}$ with VHE obtained from PHAST model simulation (VHE revealed a higher correlation between $\mathrm{VHE}_{\mathrm{T}}$ and $\mathrm{VHE}$ PHAST $\left(\mathrm{R}^{2}=0.96\right)$ than with $\mathrm{VHE}_{\mathrm{Rn}}$ $\left(\mathrm{R}^{2}=0.76\right)$. Furthermore, vertical hydraulic conductivity $\left(\mathrm{K}_{\mathrm{v}}\right)$ of the sediment-bed materials, calculated in situ by the permeameter test, indicated not only that $\mathrm{K}_{\mathrm{v}}$ was up to $21 \%$ higher in areas dominated by upward movement than at downwelling points, but also principle component analysis (PCA) demonstrated the dependence of Kv on porosity, VHE, and \%sand of the stream-bed materials. This study provides evidence that vertical flux in the hyporheic zone is mainly affected by stream sinuosity and regional subsurface flow, and that the temperature method is more suitable than radon activity to quantify hyporheic exchange patterns.

Key words: vertical hyporheic exchange, ${ }^{222} \mathrm{Rn}$, temperature, residence time, PHAST simulator, Ghezel-Ozan River

\section{Introduction}

Infiltration of stream water into saturated sediments beneath stream bed, and then exfiltration

20 into the stream after intra-sediment residence time (Gooseff, 2010; Tonina, 2012), is recognized as hyporheic exchange. The hyporheic zone, consisting of the saturated and kinematic zones beneath and adjacent to the stream bed which connect to the river aquifer system, is known as a key area for regulation of the dynamic biogeochemical properties of the exchange water (Deng et al., 2015). Therefore, accurate quantification and identification of the 
spatial patterns of the hyporheic exchange process plays a crucial role in determining the fate and transport of anthropogenic contaminants (Meghdadi and Javar, 2018).

Hyporheic exchange is mainly governed by riverbed morphological features such as riffle-pool sequences (Gariglio et al., 2013), stream sinuosity and curvature (Meghdadi and Eyvazi, 2017; Zhang et al., 2017), and stream sedimentary properties (Song et al., 2017). These complex and varied stream morphological features increase the difficulties in understanding the magnitude of the hyporheic exchange.

Riffle-pool sequences in the thalweg areas of a meandering river are characterised by complex morpho-dynamic (Bätz et al., 2016) and hydrodynamic features, which create a sequence of stagnation and accretion zones in the direction of river flow. As a result, the magnitude of the hyporheic exchange is highly affected by the morphological variations (Lambs, 2004). Hence, understanding the effect of the different hydrodynamic and morphological variations on the vertical hyporheic flux patterns plays a pivotal role in appropriate regulatory decision making concerning contaminants (Criswell, 2016). The stream sediment vertical hydraulic conductivity is another key parameter for analysis of stream-aquifer connectivity and, due to variation in river morphology, is closely linked to the hyporheic exchange (Stewardson et al., 2016).

Environmental natural tracers have been widely proposed to assess the vertical hyporheic exchange (VHE) in river-aquifer systems. Three environmental tracers that have been applied for this purpose are temperature, electrical conductivity (EC), and radon $\left({ }^{222} \mathrm{Rn}\right)$. Comparison of the magnitude of diel temperature variations in stream and subsurface sediments, at one or more depths, provides a useful insight into the magnitude and direction of hyporheic water flux. Typically, in upwelling location subsurface sediments the diel temperature is lower, whereas a rapid increase in subsurface diel temperature results from downward hyporheic flux. 
Radon, which is a short-lived radioactive gas, is employed as a tracer for up to medium-term residence time ( $<15$ days) when flux assessment is of particular interest (Atkins et al., 2016). River water infiltrate into subsurface sediments brings about a rapid increase of the radon activity of the infiltrated water with time, and allows the water characteristics to be measured

5 (Cook et al., 2011). EC in hyporheic zones where the groundwater endmembers have distinct signatures can be employed to distinguish between stream water and regional subsurface flow (McCallum et al., 2010).

Radon and temperature have been widely suggested for quantification of VHE, but there has been limited research to investigate their reliability in accurately estimating hyporheic residence time and hyporheic flux. Choosing between radon and temperature is a key challenge for precise estimation of hyporheic exchange. For example, Rau et al. (2012) experimentally determined that the temperature-derived flux in homogeneous saturated sediments was up to $20 \%$ higher than the radon-derived flux, with this difference arising from inhomogeneous heat transport through the sediments. In another study, Schornberg et al. (2010) demonstrated that the disparity between temperature-derived and radon-derived flux dramatically increased with increased variation in sediment hydraulic conductivity.

Recently, Gooseff et al. (2009) performed a study to model upwelling and downwelling locations in hyporheic zone of mountain streams using longitudinal channel unit spacing profile. In other study, Wondzell et al. (2009) tested groundwater flow models to evaluate the amount of residence time and exchange flow in hyporheic zone of a mountain stream and they showed that a model accuracy strongly influenced by the choice of nodal spacing as well as procedures applied to interpolate spatially distributed parameters to the model domain. Furthermore, Constantz (2008) reviewed the application of heat as a tracer to assess shallow ground water movement and described the recent temperature-base approached to evaluate 
hyporheic exchange. The storage capacity of hyporheic sediment was assessed recently by Neilson et al. (2010) via simultaneous application of temperature and solute model to better calculate transient storage modelling approaches.

Modelling tools provide another indispensable approach to visualise the spatial distribution of previously studied simulation models PHREEQC and HST3D, was used to model a wide range of kinetic and geochemical reactions (Parkhurst et al., 2010). PHAST is capable of quantitative visualisation of the downward and upward flux locations of stream beds. In brief, it employs a set of partial differential equations for solute transport and a set of nonlinear algebraic differential equations for solute chemistry. The saturated groundwater flow equation is applied in the model to estimate total subsurface fluid mass (Parkhurst et al., 2010). The subsurface solute transport and flux equations are integrated via the dependence of advective-dispersive transport on the interstitial flux-velocity field. By applying a successive solution approach for flux reaction and transport calculations, numerical results are obtained for each of the dependent variables including, solute and species concentration, potentiometric head, and the mass of reactants in each grid cell.

Hence, providing an innovative alternative framework incorporating both morphological and physio-chemical characteristics of streams which can be quantitatively applied for more accurate spatial evaluations and modelling of the hyporheic exchange within thalweg paths of sinusal streams is area of active research. Therefore, the aims of this study were to: (a) characterise the hydraulic and morphological features of the thalweg paths of meandering streams and understand the spatial distribution of hydraulic conductivity; (b) to quantify vertical hyporheic exchange in thalweg paths characterised by riffle-pool sequences; (c) apply the vertical variations of diel temperature, radon, and EC to determine the depth-dependent 
variability of subsurface flux; and (d) investigate the suitability of PHAST modelling technique to estimate VHE and associated residence times, and verify the accuracy of the modelling results against radon and temperature.

\section{Sampling and study area description}

\subsection{Study area}

This study was conducted in the Tarom watershed, which is a sub-basin of the Ghezel-Ozan watershed. The Tarom watershed is located at $37^{\circ} 01^{\prime} 48^{\prime \prime}$ to $36^{\circ} 54^{\prime} 36^{\prime \prime}$ latitude and $48^{\circ} 44^{\prime} 24^{\prime \prime}$ to $48^{\circ} 54^{\prime} 24^{\prime \prime}$ longitude, covering a total area of $113 \mathrm{~km}^{2}$ (Figure 1A). The Ghezel-Ozan River passes through the Tarom valley and is approximately $80 \mathrm{~km}$ north-west of Zanjan city. The river is a highly meandering stream and consists of multiple riffle-pool sequences and sandy clay alluvial sediment textures. Igneous bedrock is the dominant geochemical unit underlying the river sediments. Furthermore, the geology of the study watershed is mainly late Tertiary to early Quaternary calcareous sands, basalt, and clay (Meghdadi and Eyvazi, 2017). Four zones located in the thalweg path of the sinuously flowing stream and characterised by different morphological and hydrodynamic features (multiple riffle-pool sequences, Figure 1A) were chosen to fulfil the study requirements.

\subsection{Sampling and field data measurements}

Field data sampling was carried out along more than $1600 \mathrm{~m}$ of the Ghezel-Ozan River. Due to the suggestion by Anibas et al. $(2011,2009)$ and Gariglio et al. $(2013)$ that winter is the most

20 favourable time for assessment of the thermal process, the sampling procedure was conducted from 02 January 2019 to 16 January 2019 across the four separate zones. In total there were 33 testing points and 11 cross sections arranged perpendicularly or parallel to the stream flow direction (Figure 1B). A set of 33 multi-level sampler (MLS) piezometers (Meghdadi and Eyvazi, 2017) was constructed using galvanized steel pipe with inside diameter (ID) of $70 \mathrm{~mm}$ 
and an end-fitted steel drive point that was vertically driven into the river sediments at each testing point using a sledge hammer. Five Solinst TLC level loggers were placed into each MLS and fastened with a steel cable to the threaded lid (Figure 1B). The level loggers were calibrated before and after each measurement to $\pm 0.5^{\circ} \mathrm{C}$ accuracy. The TLC level loggers were set at $0.25,0.45,0.65,0.85$ and $1.05 \mathrm{~m}$ depths and recorded the temperature at each depth at 30 minute time intervals, which is the time interval required to satisfy the requirements of the sediment thermal calculation under unsteady state flow conditions (Boano et al., 2013).

Besides the data loggers, at each of the five depths, flexible polytetrafluoroethylene (PTFE) water sampling tubes with $5 \mathrm{~mm}$ ID connected to a peristaltic pump were employed for pore water sampling (Figure 1B). Furthermore, a $1.5 \mathrm{~m}$ long high-density polyethylene tube with 70 mm ID and fitted with a stainless steel drive point, for ease of penetration into sediments, was employed to measure the hydraulic head (Figure 1B). The piezometer had a $10 \mathrm{~mm}$ aperture located $12 \mathrm{~mm}$ above the stainless steel joint and was used to measure the hydraulic head once at each testing point.

Three sediment cores from each zone were collected, making 12 cores in total, using 3" Shelby tube samplers (Forsum Ultra-hard Material Industry Co. Ltd, China) to minimise sample disturbance and calculate soil-related parameters such as porosity, D50 (mid-point range of the particle size distribution), bulk density, and pore water radon equilibrium activity. To measure the radon activity, surface water samples at $0.05 \mathrm{~m}$ depth, and sediment pore water samples from the five aforementioned depths at each of the 33 testing points, were collected using MLS and stored in $40 \mathrm{~mL}$ glass bottles, then the radon activity was calculated in the field using $\mathrm{RAD \&}-\mathrm{H}_{2} \mathrm{O}$ (Durridge $\mathrm{Co}, \mathrm{MA}$, USA). The RAD\&- $\mathrm{H}_{2} \mathrm{O}$ were formerly calibrated to a precision of approximately $1 \%$. To measure the radon equilibrium activity of the aquifer sediments, soil samples were collected in $250 \mathrm{~mL}$ pre-rinsed borosilicate glass bottles then filled completely with distilled water and sealed so that no air remained in the bottle. These 
were left in the laboratory at $20{ }^{\circ} \mathrm{C}$ for 1.5 months to reach the equilibrium concentration. Triplicate water samples were sent to the geochemical laboratory at the University of Zanjan for equilibrium concentration analysis using the liquid scintillation method (Leaney and Herczeg, 2006). A hand held YSI probe ( $\pm 1 \%$ accuracy) was employed to measure the EC in the field. All the sampling and in situ data measurement procedures described above were carried out based on the criteria described by APHA (2005). The quality control and quality assurance (QC/QA) procedures for all the above-mentioned in situ analyses were achieved using three replicas of each experimental phase and analysis of one surrogated blank per 25 samples. Results from analysis of the replicas were within $\pm 5 \%$ of the standard deviation (Hounslow, 1995).

\section{Methodology}

\subsection{Temperature}

Diel temperature variation in the hyporheic zone and surface water bodies provides a useful insight for estimation of the magnitude of VHE between the two water bodies. In this study, the conductive-advective heat transport procedure employing the one-dimensional advectivediffusion equation was applied to quantify the groundwater/surface water exchange rate and evaluate the hyporheic vertical flow pattern (Hyun et al., 2011). The equation for onedimensional advection-diffusion heat transport can be expressed as equation 1 (Hatch et al., 2006; Naranjo et al., 2013):

$20 \quad \frac{\partial T}{\partial t}=k_{e} \frac{\partial^{2} T}{\partial z^{2}}-\frac{q}{\gamma} \frac{\partial T}{\partial z}$

where $\mathrm{T}$ is stream-bed temperature $\left({ }^{\circ} \mathrm{C}\right), \mathrm{t}$ is time $(\mathrm{s}), \mathrm{z}$ is vertical depth in the stream-bed $(\mathrm{m})$, $\mathrm{k}_{\mathrm{e}}$ is the effective thermal diffusivity $\left(\mathrm{m}^{2} /\right.$ day), $\mathrm{q}$ is the Darcy vertical pore water flux ascribed to pore water velocity ( $\mathrm{v}$ in $\mathrm{ms}^{-1}, \mathrm{v}=\mathrm{q} / \theta$, where $\theta$ is the porosity of the saturated sediments), and 
$\gamma$ is the ratio of the volumetric heat capacity of saturated sediments $(\rho \mathrm{C})$ to the heat capacity of water $\left(\rho_{\mathrm{f}} \mathrm{C}_{\mathrm{f}}=4.22 \times 10^{6} \mathrm{~J} /\left(\mathrm{m}^{3} \mathrm{~K}\right)\right)$; the magnitude of $\rho \mathrm{C}\left(2.71 \times 10^{6} \mathrm{~J} /\left(\mathrm{m}^{3} \mathrm{~K}\right)\right.$ is derived based on the procedures described by Waples and Waples (2004). The values of $\gamma$ and $\mathrm{k}_{\mathrm{e}}$ applied in this study were obtained from the experimental relationships established in the literature (Lapham,

5 1989; Lunardini, 1981) for sandy-clay soil $\left(\mathrm{k}_{\mathrm{e}}=2.44 \times 10^{6} \mathrm{~J} \mathrm{~s}^{-1} \mathrm{~m}^{-1} \mathrm{~K}^{-1}\right)$. The diel temperature variation of the river were approximated with a sinusal function and the Equation 1 was analytically solved to calculate the vertical water flux. In the Equation 1, the upper boundary corresponds to the stream bed surface $(\mathrm{z}=0$ where $\mathrm{TZ}=\mathrm{T} 0)$ and the lowermost sampling depth ( $\mathrm{Z}=\mathrm{L}, \mathrm{L}=1.05 \mathrm{~m}$ ) sets the lowest boundary $(\mathrm{Tz}=\mathrm{TL}$ at $\mathrm{z}=\mathrm{L})$. ). Considering the boundary condition, equation 1 can be expressed as equation 2 :

$\frac{T-T_{0}}{T_{L}-T_{0}}=\frac{e^{\beta z / L}-1}{e^{\beta-1}}$

where $\beta$ is equal to $\rho_{f} C_{f} q L / k_{e}$ (dimensionless parameter), which is negative for upwelling flux and positive for downwelling flux. As described by Arriaga and Leap (2004), the value of $q$ is proportionate to the $\beta$ value: when $\beta$ is positive, $q$ is positive. The temperature values at 20 locations in the sediment layers were used to calculate the $\beta$ value and subsequently solve equation 2 . The diel temperatures at each of the 33 testing points were simulated independently using parameter estimation software PEST (Doherty, 2010), which showed the temperature profile over each 12 hour period of the total 24 hour recording time. During the PEST analysis the sum of the square error between the observed and simulated temperature data was minimized via repetitive variation of q until the line of best fit was achieved. The VHE derived from temperature values $\left(\mathrm{VHE}_{\mathrm{T}}, \mathrm{m} /\right.$ day) were obtained by solving equation 2 using the Microsoft Office Excel solver add-in to calculate $\beta$, then based on the method described by Arriaga and Leap (2006), as equation 3 the VHE can be achieved:

$$
|V H E|=\frac{K_{e} \beta}{C_{f} \rho_{f} L}
$$


The magnitude of the temperature-derived residence time $\left(\operatorname{tr}_{\mathrm{T}}\right)$ at each depth $(\mathrm{z})$ can be

calculated as $t_{r T}=\frac{z \theta}{V H E_{T}}$. The upper and lower uncertainty ranges of $\operatorname{tr}_{\mathrm{T}}$ were determined by the Monte Carlo analysis (parameter optimisation method), considering over 580 simulations of temperature transport values and different $\mathrm{k}_{\mathrm{e}}$ and VHET magnitudes. Random $\mathrm{k}_{\mathrm{e}}$ values were generated by assessing a uniform distribution of the estimated $\mathrm{k}_{\mathrm{e}}$ up to a variation of $\pm 50 \%$.

\subsection{Vertical hydraulic conductivity}

Vertical hydraulic conductivity $\left(\mathrm{K}_{\mathrm{v}}\right)$ is an important hydraulic parameter for estimating the interaction between groundwater and surface water (Jiang et al., 2015). In this study, the magnitude of the stream bed hydraulic conductivity was calculated using equation 4 from measurements at each of the 33 testing points (all the calculation process were performed based on the procedures described by Song et al. (2017).

$K_{v}=\frac{L_{v}}{t_{2}-t_{1}} \times \operatorname{Ln}\left(\frac{h_{1}}{h_{2}}\right)$

In equation $4, h_{1}$ and $h_{2}$ are the hydraulic heads measured at time $t 1$ and $t 2$, respectively, and $L_{v}$ is the stream sediment thickness in metres (Figure 1B). The length of $L_{v}$ was approximately $1.05 \mathrm{~m}$ and the average ratio of $\mathrm{K}_{\mathrm{v}}$ to ID was 7.9. As an assessment of the accuracy and applicability of the equation 4 method, the calculated values of the potential errors for the $\mathrm{K}_{\mathrm{v}}$ measurement were less than $5 \%$. Hence, the associated in situ measured parameter (during the rest period) could be employed to assess the magnitude of $\mathrm{K}_{\mathrm{v}}$. Furthermore, to identify the most influential parameters on $\mathrm{K}_{\mathrm{v}}$, orthogonal projection and transformation analysis of soil physical and hydrodynamic parameters (\%sand, \%silt, \%clay, $\mathrm{t}_{\mathrm{r}}, \mathrm{D}_{50}$, flux velocity, porosity, VHE, $\mathrm{f}$, and stream depth) was performed using principle component analysis.

\subsection{Radon}


Noble gas radon $\left({ }^{222} \mathrm{Rn}\right)$, with a half-life of 3.82 days, is found both in streams and aquifers. ${ }^{222} \mathrm{Rn}$ is produced by radium $\left({ }^{226} \mathrm{Ra}\right)$ decay: dissolved radium can attach to the aquifer matrix under low salinity conditions (Cook and Herczeg, 2012) and the dissolved radon concentration in groundwater increases over time due to ${ }^{222} \mathrm{Rn}$ production in the aquifer sediments until an equilibrium is reached. However, the magnitude of the equilibrium concentration measured from the sampled sediments was dependant on the radon activity rate of the aquifer material, as approximately four weeks is required for complete equilibrium to be attained. Theoretically, the amount of water that entered the aquifer within this time can be measured. In this study, the radon activity at time $\mathrm{t}$ (equation 5) was applied to estimate the radon-derived VHE rate ( $\mathrm{VHE}_{\mathrm{Rn}}, \mathrm{m} /$ day), as follows (Cecil and Green, 2000):

$A_{t}=A_{e}\left(1-e^{-\lambda t_{r R n}}\right)+A_{0} e^{-\lambda t_{-} r R n}$

In equation $5, \mathrm{~A}_{t}, \mathrm{~A}_{e}$, and $\mathrm{A}_{0}$ refer to the radon activity at time $\mathrm{t}$, equilibrium, and initial time of sampling ( $t=0$ ), respectively. $\lambda$ is the ${ }^{222} \mathrm{Rn}$ decay coefficient which is $0.181 /$ day, and $t_{r R n}$ is the radon-derived residence time which can be achieved by solving equation 5 . The uncertainty range of $t_{r R n}$ was evaluated for each of the 33 testing points employing the Monte Carlo uncertainty analysis procedure (at $5^{\text {th }}$ and $95^{\text {th }}$ percentiles). The mean and standard deviation values of the radon activity of stream water, and at equilibrium in the sediment pore waters, were applied to generate the normal distribution pattern of $\mathrm{A}_{0}$ and $\mathrm{A}_{\mathrm{e}}$. About 3590 simulations of the Monte Carlo analysis considering $\mathrm{A}_{\mathrm{e}}$ and $\mathrm{A}_{0}$ were used to define the upper and the lower error boundaries of $\mathrm{t}_{\mathrm{rRn}}$. The estimated $\mathrm{t}_{\mathrm{rRn}}$ was converted to the radon-derived VHE according to $\mathrm{VHE}_{\mathrm{Rn}}=\mathrm{z} \theta / \mathrm{t}_{\mathrm{rRn}}$.

\subsection{PHAST modelling}


The computer simulation program PHAST (PHREEQC and HST3D) is a versatile model which can simulate solute transport in two- and three-dimensional (2D/3D) saturated groundwater systems (Parkhurst et al., 2010). The calculation of flow transport is based on the modified HST3D version. The major benefit of PHAST is to allow input of the 2D spatial distribution of groundwater flux using a combined map of the grid coordinate system rather than node by node data insertion. Different boundary conditions including specified flux, specified head difference, and head-dependent flux, are available in the software. Furthermore, output data (HDF files) can be visualized in 2D format using the ModelMuse graphical interface (Bushira et al., 2017).

In this study, to simulate vertical hyporheic flow the model values for porous media, grids, initial and boundary conditions, solute transport, and time intervals, were defined in the model based on the data file provided by Zanjan's Natural Resources Office Division of Water Resources Management (http://www.frw.org.ir/00/En/default.aspx). The initial water table in PHAST applied the 2D data set that is only defined in the model for one layer of nodes.

The river boundary condition (RIVER data block) was used to simulate the river aquifer water exchange which uses the sign of head difference between aquifer and the river, the layer thickness, and the hydraulic conductivity to assess the water exchange between two water bodies. For this study, the river boundary condition was transformed into source terms on the cell by cell basis which the discretised equation for a river segment (s) and for the water table cell (wt) is described as equation 6 , as follow:

$Q_{R s}=\frac{K_{R s}}{b_{R s}}\left(h_{R s}-h_{w t}^{n}\right) S_{R s}-\frac{K_{R s}}{b_{R s}} S_{R s} \delta h_{w t}$

Where $\mathrm{Q}_{\mathrm{Rs}}$ is the volumetric flowrate for river segment $(\mathrm{m} 3 / \mathrm{s}), \mathrm{b}_{\mathrm{Rs}}$ is the riverbed thickness for the segment $\mathrm{s}(\mathrm{m}), \mathrm{K}_{\mathrm{Rs}}$ riverbed hydraulic conductivity for the segment $\mathrm{s}(\mathrm{m} / \mathrm{s}), \mathrm{h}_{\mathrm{Rs}}$ is potentiometric head for segment $\mathrm{s}(\mathrm{m}), \mathrm{n}$ refers to the discrete of the time value during the 
simulation, $\mathrm{S}_{\mathrm{Rs}}$ denotes the area of the river segment $\left(\mathrm{m}^{2}\right)$, and $\delta_{\mathrm{hwt}}$ refers to the variation of the water-table elevation over the time (m).

\section{Results and discussion}

\subsection{Morphological characteristics of the study zones}

5 Detailed streambed elevation data from the four study zones is illustrated in Figure 2. In each of the four zones the clear riffle-pool sequences, as well as the erosional zone in the vicinity of the thalweg path, and the depositional zone, could be observed. The different bed-form structure in association with the distribution of sediment grain size was used to characterise the depositional and erosional areas, with the erosional zones mainly observed at the left bank side of the parafluvial area toward the thalweg paths.

In addition, based on the river bed morphology and sediment characteristics, 33 testing points along the riffle-pool sequence of the meandering river were identified. Based on the platform geometry and flux momentum, these sampling points were clearly interconnected (Hiatt and Passalacqua, 2015). The study zones were in a region of river sinuosity, and contained several riffle-pool sequences with flux momentum of $<0.5$ and acute angle, causing stagnation and decreased flow velocity (Riley et al., 2015); the flux momentum ratio $\left(\mathrm{M}_{\mathrm{r}}<0.5\right)$ and sharp river curvature leads to anomalies in river bed sediment temperature especially during high flow conditions (Riley and Rhoads, 2012; Xian et al., 2017; Zhang et al., 2017). In contrast, downstream of the river deflection is characterised as a flow accelerator and recovery zone.

20 The sequences of flow accelerator and diffraction areas, and their integration with riffle-pool sequences, provides a complex river-aquifer interaction mechanism. The area selected for this study was in accordance with the approach of Johnson (2015), where the succession of river accretion and deflection zones played a significant role in identification of subsurface flux patterns and quantification of the magnitude of VHE. 
Grain size distribution and median grain size and porosity had a clear influence on the vertical hydraulic conductivity $\mathrm{K}_{\mathrm{v}}$ and VHE. The parameters relating to sediment grain size distribution in zones 1-4 are provided in Table 1 from which it can be seen that there was a high cumulative percentage of grain sizes between $0.075 \mathrm{~mm}$ and $2 \mathrm{~mm}$ observed in each of the zones.

\section{$5 \quad 4.2$ Assessing the vertical hydraulic conductivity of sediments}

The values of $\mathrm{K}_{\mathrm{v}}$ ranged from 0.27 to $3.76 \mathrm{~m} /$ day with a coefficient of variation $(\mathrm{CV})$ of 0.45 to 0.69 . These low $\mathrm{CV}$ values are typically ascribed to the sandy clay soil texture of the river sediment which exerts an important controlling factor on $\mathrm{K}_{\mathrm{v}}$ (Chen et al., 2013; Jorda et al., 2015). The orthogonal transformation and projection of the physical and hydrodynamic related parameters on $\mathrm{K}_{\mathrm{v}}$ were described using the principle component analysis (PCA) method (Donath et al. (2015); Figure 3).

The PCA results accounted for more than $65 \%$ of the total variance $(\mathrm{PC} 1=48.3 \%$ and $\mathrm{PC} 2=17.2 \%$ ). There was significant correlation between temperature-derived $\mathrm{K}_{\mathrm{v}}$ and VHE (see section 1) and porosity, as well as with percentage of sand $(\mathrm{p}<0.05)$, which suggested that it was the properties of the river-sediment grain that had the highest impact on $\mathrm{K}_{\mathrm{v}}$. The second principle component (PC2) accounted for lower variance, but the high value of PC2 for $\mathrm{D}_{50}$ $(\mathrm{p}<0.05)$ could indicate the controlling effect of the magnitude of the median grain size on $\mathrm{K}_{\mathrm{v}}$. The negative value of the first principal component for temperature-derived residence time with $\mathrm{K}_{\mathrm{T}}(\mathrm{p}<0.05)$ was logical due to the reciprocal trend in residence time with change in vertical hydraulic gradient. The reason for the negative correlation between $\mathrm{K}_{\mathrm{v}}$ and silt\&clay percentage could be due to a lower percentage of clay and silt in the vertically sampled sediment core (from the river-bed) having a sediment pore clogging effect, and therefore exerting a limiting influence on f. Moreover, clay and silt exhibit distinctly different behaviour during downward and upward flux: in downwelling flow, the small particles fill the sediment 
pore spaces; in upwelling flow, the small particles move out of pore spaces. These differences explain the variation of $\mathrm{K}_{\mathrm{v}}$ and porosity in river-bed sediments (Datry et al., 2015).

\subsection{Quantifying the magnitude of $\mathrm{VHE}$ and residence time}

The magnitude of radon activity $\left(\mathrm{BqL}^{-1}\right)$ and diel temperature variation at the different sediment depths were measured to assess the magnitudes of temperature-derived and radon-derived VHE (VHE $\left(\mathrm{VHE}_{\mathrm{t}}\right.$ and $\mathrm{VHE}_{\mathrm{Rn}}$, respectively), and the associated residence times $\left(\operatorname{tr}_{\mathrm{T}}\right.$ and $\left.\mathrm{t}_{\mathrm{rRn}}\right)$ in the four riffle-pool areas of the meandering stream. The in-situ sampling procedure was conducted at depths of 0 (surface water), 5, 25, 45, 65, 85, and $105 \mathrm{~cm}$ below the sediment bed.

Based on the temperature and radon activity variations in different sediment layers, the magnitude of VHE was estimated at the 33 testing points located parallel and perpendicular to the riffle-pool areas (Figure 1A). The one-dimensional heat transport model (Equation 1) was used to estimate the temperature-derived $\mathrm{VHE}_{\mathrm{t}}$ (Table 2). The positive and negative $\mathrm{VHE}_{\mathrm{t}}$ values reflected downwelling and upwelling water movement, respectively (Hyun et al., 2011). The $\mathrm{VHE}_{\mathrm{t}}$ values ranged from $-1082 \mathrm{~mm} /$ day to $1803 \mathrm{~mm} /$ day, indicating considerable variation due to the complex geomorphological conditions of the thalweg paths (Kasahara and Wondzell, 2003). The temperature-derived and radon-derived $\operatorname{VHE}\left(\mathrm{VHE}_{\mathrm{T}}\right.$ and $\mathrm{VHE}_{\mathrm{Rn}}$ ) at the 33 sampling points are illustrated in Figure 4.

The values of $\mathrm{VHE}_{\mathrm{t}}$ along the riverbed sediments of each zone reflected the significant subsurface lateral flow, which is dominated by downward flow in the pools and upward movement in the riffle segments. The highest $\mathrm{VHE}_{\mathrm{t}}$ values (Figure 4) occurred in B18 (1803 mm/day), B7 (1044 mm/day), B22 (1008 mm/day), B6 (986 mm/day), B23 (-1082 mm/day), B10 (-1050 mm/day), and B8 (-890mm/day); these locations contained the lowest amounts of silt and clay. This was in agreement with results reported by Kennedy et al. (2009), where high $\mathrm{VHE}_{\mathrm{t}}$ values resulted from the abundance of sand and gravel content in river bed sediments 
and erosional zones along the thalweg paths, and high $\mathrm{K}_{\mathrm{v}}$ values. Furthermore, the downwelling patterns were mostly observed at the river boundaries (river bank), such as B1, B7, B16 and B22 (Figure 2), whereas the testing points located at the central sections of the river and with higher elevation, such as B2, B10, B17, B23 and B26, exhibited upward exfiltration of water into the stream. The downward infiltration is driven by river sinuosity and the upward movement is mainly caused by the higher groundwater level (during winter), in this region (Cardenas, 2009). Stream sinuosity areas are considered as kinematic zones influenced by gradient pressure between downstream and upstream along river bends (Boano et al., 2014), where gradient-driven hyporheic flux forms the local flow paths. These complex flow paths indicate the effect of regional and local hyporheic flow patterns which play a significant role in regulation of the biogeochemical processes (Gomez-Velez et al., 2015).

To accurately estimate VHE, in situ radon activities were measured. The stream had a mean radon activity of $0.61 \pm 0.13 \mathrm{~Bq} / \mathrm{L}$, based on 41 surface water samples collected between 11 am and 6 pm on 8 February, 2015). The radon activity showed spatial variation, with a mean value

15 for the surface water samples of $0.38 \pm 0.098 \mathrm{~Bq} / \mathrm{L}$ and $0.93 \pm 0.28 \mathrm{~Bq} / \mathrm{L}$ in the riffle and pool cross sections, respectively. The main reason for the discrepancies in stream radon activity could be attributed to the change in stream water gas transfer velocity due to changes in the river depth and width across the riffle-pool sections (Cranswick et al., 2014). For example, in $\mathrm{Z} 1$ the mean river depth and width were $0.89 \mathrm{~m}$ and $213 \mathrm{~m}$, respectively, but in $\mathrm{Z} 4$ these values were $2.05 \mathrm{~m}$ and $74.4 \mathrm{~m}$, respectively. Also, the probable discharge of groundwater in riffle segments was another likely cause of disparity in stream radon values, including the negative values (Figure 4). The increase in surface water radon activity was strengthened by upward gradient, which was mostly observed across the riffle sections. The mean radon activities of the alluvial aquifer at the deepest sampling point $(105 \mathrm{~cm}$ below the river-bed) ranged from 
2.02Bq/L (B7) to $8.19 \mathrm{~Bq} / \mathrm{L}(\mathrm{B} 30)$ with a mean standard deviation of $4.58 \pm 1.84 \mathrm{~Bq} / \mathrm{L}$ (Figure

$5)$.

Considering the results presented in Figure 4, it was evident that at testing points where groundwater exfiltration occurred, $\mathrm{VHE}_{\mathrm{Rn}}>\mathrm{VHE}_{\mathrm{T}}$, while at downwelling points such as $\mathrm{B} 1$ or $5 \mathrm{~B} 18$, the VHE was overestimated by temperature $\left(\mathrm{VHE}_{\mathrm{Rn}}<\mathrm{VHE}_{\mathrm{T}}\right)$. These discrepancies could possibly be ascribed to sub-surface lateral flow, the degree of aquifer-sediment heterogeneity, and the potential thermal transport heterogeneity associated with the sediments (Irvine et al., 2015; Rau et al., 2012). Furthermore, at some testing points such as B7, B10 and B18, the difference between $\mathrm{VHE}_{\mathrm{T}}$ and $\mathrm{VHE}_{\mathrm{Rn}}$ was significant. To further investigate these discrepancies, the vertical variations in diel temperature, radon activity and EC at 5, 25, 45, 65, 85 and $105 \mathrm{~cm}$ depths below the sediment bed) were measured (Figure 6 and Figure 7).

For profiles B3, B11, B13, and B19, the EC variation was relatively constant at different depths. There was increased diel temperature variation and a slight increase in the radon activity of the sediments, which was due to infiltration of groundwater. In the profiles with low downwelling/upwelling rates (e.g. B2, B10, B20, Figure 5), as depth increased there was increased EC, but decreased radon activity and temperature. In locations with high rates of upward flux (B29 and B32), the temperature envelopes represented constant temperature at different depths, but dramatically increased radon and EC values.

Radon activity was augmented at mid-depths of profiles such as B1, B10, B15, B23, B26, B29 and B32, and in some cases these values were higher than the radon activity reported by Meghdadi and Eyvazi (2017) for alluvial aquifers. This could be due to heterogeneity in the sediment radon production rate arising from variation in metal oxide radium adsorptiondesorption, which mostly occurs at redox boundaries, or the sediment mineralogical heterogeneity (Lamontagne et al., 2011). Therefore, the sudden increase in radon activity at 
mid-depths was due to geochemical processes occurring within the hyporheic zone or the sediment mineralogical heterogeneity.

Profiles B2, B3, B15, B17, B20, and B26 appeared to have downwelling flow at shallow depths of up to $0.45 \mathrm{~m}$ below the riverbed, because of the large diel temperature variations and low radon and EC activities. However, at higher profundities $(>45 \mathrm{~cm})$, upward flux was indicated by the constant temperature and sudden increase in radon activity and EC, except for at B3. These opposing flow patterns occurred mostly at depths greater than $45 \mathrm{~cm}$, except for at B17 and $\mathrm{B} 32$ where this occurred at $25 \mathrm{~cm}$, providing evidence that hyporheic flux is a part of a larger regional flow field. The high magnitudes of EC and radon at the greatest sampling depth $(105 \mathrm{~cm})$ at $\mathrm{B} 10, \mathrm{~B} 13, \mathrm{~B} 26, \mathrm{~B} 29, \mathrm{~B} 30$ and $\mathrm{B} 32$ were a result of interaction between groundwater from shallow aquifers with hyporheic water, mostly in areas that were close to alluvial stream channels. On the other hand, the relatively constant values of radon and EC in upwelling profiles such as B20, B17 and B22 did not display the elevated radon activity at the deepest testing points, which indicated that upward fluxes originated from the hyporheic shallow water instead of larger groundwater sources.

The general assessment of flow direction, considering all the information from positive and negative VHE values, and EC, temperature and radon profiles, was as follows: in the pool segments the hyporheic flow was downward then switched to horizontal flow, then finally groundwater ex-filtration occurred in riffles. Similar trends have been reported by Cranswick et al. (2014) and Cook et al. (2004).

\subsection{Simulation of spatial distribution of VHE using the PHAST simulator}

Using radon activity and temperature to quantify the magnitude of VHE in thalweg paths characterised by riffle-pool sequence morphology is confounded by the complex subsurface patterns. These arise from heterogeneity in the sediment mineralogical properties, hyporheic 
water interaction with regional groundwater flow, and geochemical interactions between sediment and hyporheic flow see section 4.3). To address this difficulty it was decided to apply simulation models (Käser et al., 2014).

Accordingly, the spatial distribution of VHE was simulated using PHAST modelling, not only

5 to achieve conceptual insights relating to the spatial variations of VHE in the meandering channels, but also to assess the operational accuracy of the simulator against temperature and radon to quantify VHE in the thalweg paths containing multiple riffle-pool sequences. The model properties following set up and calibration procedures are briefly described in the following sections.

After employing the input files (for more information see Parkhurst et al. (2010) and Winston, 2009), the model was run more than 3000 times to simulate hyporheic exchange. The performance of the model in estimating the vertical flow direction (VFD) in each zone was tested using a plot of residuals vs vertical head difference (VHD), which is illustrated in Figure 8A. The ratio of the absolute values of residuals $(\varepsilon)$ to the absolute values of VHD were applied to assess the reliability of the results. If the ratio of $|\varepsilon| / \mid$ VHD $\mid$ is less than one, this indicates that the model performance is reliable (Käser et al., 2014). The vast majority of simulated VHD values were larger than the associated residuals in each of the four zones (Figure 8A), which indicated that the model more correctly characterised the hyporheic flux. Therefore, the model was considered to be a valid simulator of VHD and VHE.

20 However, although the model provided a reliable prediction of the hyporheic flow patterns, in Z3 and Z4 the model slightly overestimated the VHD, especially in downwelling segments, and underestimated the upwelling heads. This discrepancy in the model performance may have been caused by an overly significant influence of the limited downwelling points on the model calibration (Stewardson et al., 2016; Wondzell et al., 2009). Because the model operates on the 
basis of equal weighting to each observation, overestimation of the head gradient may have occurred in the model set up. The model was not initially designed for heterogeneous basal flux, so that in the model the linear variation of basal flux conducted among the lateral boundaries would lead to increased hydraulic gradient on one side and decreased on the other side.

The reliability of the model calibration was investigated in each zone separately considering the magnitude of the root mean square error (RSME) and mean absolute error, as follows:

$$
\begin{aligned}
& R M S E=\sqrt{\frac{1}{n}} \sum_{i=1}^{n}\left(h_{s i m, i}-h_{o b s, i}\right)^{2} \\
& M A E=\frac{1}{n} \sum_{i=1}^{n} h_{s i m, i}-h_{o b s, i}
\end{aligned}
$$

10 In equations 7 and $8, \mathrm{n}$ refers to the total number of measurements, $\mathrm{h}_{\text {sim,i }}$ refers to the simulated head at point $\mathrm{i}$, and $\mathrm{h}_{\mathrm{obs}, \mathrm{i}}$ refers to the observed head. The values of the observed head were defined in the model based on interpolation of the in situ head measurements and the Digital Elevation Model input file of the stream-bed sediments. The results of the error analysis indicated that the model best fit was at $\mathrm{Z4}$ (RSME=0.07 and MAE=0.13), followed by Z1 (RSME=0.09 and MAE=0.21), Z2 (RSME=0.1 and MAE=0.18), and Z3 (RSME=0.11 and $\mathrm{MAE}=0.25)$.

The spatial distribution of the VHE flux is illustrated in Figure 8B. The positions and spatial distributions of the downwelling and upwelling segments were similar to the results obtained from temperature and radon analysis. In most of the pool sections, especially in Z2 and Z4, the spatial distributions of the upwelling and downwelling locations were similar to the chosen testing points (Figure 8B). In Z1 and Z3, except for downstream of riffles, the results were quite similar to those from the radon and temperature analyses. The $7 \mathrm{~m} \times 7 \mathrm{~m}$ mesh discretisation values were employed during the simulation procedure to provide sufficient 
details of the flux spatial variations. Choosing the finer mesh size would enable more detailed flow patterns, but use of the finer mesh was not possible in this study due to the massive size of the study zones and limitations of the computer hardware to run the model.

The values of VHE obtained from temperature, radon activity and the simulation are compared

5 in Figure 8C. It was evident that the magnitudes of VHE predicted by model were more correlated with temperature-derived $\operatorname{VHE}\left(\mathrm{R}^{2} \mathrm{~T}=0.96\right.$ while $\mathrm{R}^{2}{ }_{\mathrm{Rn}}=0.76$, Figure $\left.8 \mathrm{C}\right)$. This greater correlation of the simulated results with the temperature-derived results was due to the lower sensitivity of temperature to subsurface geochemical reactions and heterogeneity in the sediment mineralogical properties compared with radon.

\subsection{Temperature-derived residence time vs radon-derived residence time}

The values of $\operatorname{tr}_{\mathrm{T}}$ and $\operatorname{tr}_{\mathrm{Rn}}$ and their associated error bars $\left(5^{\text {th }}\right.$ and $95^{\text {th }}$ percentile $)$ are illustrated in Figure 9A. The magnitude of $\operatorname{tr}_{\mathrm{T}}$ ranged from 0.9 at B23 to 5 in B16, with a mean value of $1.87 \pm 1.26$, while $\operatorname{tr}_{R n}$ varied from 0.6 at $\mathrm{B} 2$ to 4.1 at $\mathrm{B} 16$, with a mean value of $2.11 \pm 1.17$. A scattered relationship rather than a systematic relationship was observed between $\operatorname{tr}_{\mathrm{T}}$ and $\operatorname{tr}_{\mathrm{Rn}}$, as well as an evident discrepancy between $\operatorname{tr}_{\mathrm{T}}$ and $\operatorname{tr}_{\mathrm{Rn}}$ at points with high and low $\mathrm{K}_{\mathrm{v}}$. For example, at points with low $\mathrm{K}_{\mathrm{v}}$ values such as B16 $\left(\mathrm{K}_{\mathrm{v}}=0.503 \mathrm{~m} /\right.$ day $)$ and $\mathrm{B} 12\left(\mathrm{~K}_{\mathrm{v}}=0.62\right.$ $\mathrm{m} /$ day), the magnitude of $\operatorname{tr}_{\mathrm{T}}>\operatorname{tr}_{\mathrm{Rn}}$ : at $\mathrm{B} 16,5$ and 4.1 days were observed for $\operatorname{tr}_{\mathrm{T}}$ and $\operatorname{tr}_{\mathrm{Rn}}$, respectively and at B12, these values were 3.4 and 2.1 days, respectively. In contrast, at testing points where a high $\mathrm{K}_{\mathrm{v}}$ magnitude, such as $\mathrm{B} 23\left(\mathrm{~K}_{\mathrm{v}}=3.41 \mathrm{~m} /\right.$ day $)$, the $\operatorname{tr}_{\mathrm{Rn}}$ was higher than $\operatorname{tr}_{\mathrm{T}}$.

20 This finding confirmed that obtained by Ferguson and Bense (2011). Schornberg et al. (2010) provided evidence that the proximity of two contrasting hydraulic conductivity areas leads to heat-derived fluxes that do not reflect the water advective flux, especially near the boundaries of the two zones with opposing $\mathrm{K}_{\mathrm{v}}$ values. 
The values of $\operatorname{tr}_{\mathrm{T}}$ at the downwelling points (e.g. B1, B7, B16, B19, B22, B27, B30 and B31) appeared to be shorter than $\operatorname{tr}_{R n}$, and at the upwelling points (B2, B6, B15, B20, B23, B26, B29 and B32), $\operatorname{tr}_{\mathrm{T}}$ was longer than $\operatorname{tr}_{\mathrm{Rn}}$. This may suggest that in the zones where upward movements are dominant, the sediments were mostly composed of material with low $\mathrm{K}_{\mathrm{v}}$ capacity and a small proportion of the sediments consisted of high $\mathrm{K}_{\mathrm{v}}$ material, such as sand and gravel.

The measured values of $\operatorname{tr}_{\mathrm{T}}$ and $\operatorname{tr}_{\mathrm{Rn}}$ and the upper and lower uncertainty boundaries at the 95 percent confidence interval (based on the Monte Carlo analysis) are illustrated in Figures 9B and $9 \mathrm{C}$. The values of $\mathrm{A}_{0}$ and $\mathrm{A}_{\mathrm{e}}$ (from equation 5) varied randomly and followed a normal distribution, based on the mean and standard deviation of the calculated values. However, at a few points (B13, B16, B17, B18 and B31), the estimated radon-derived residence time exceeded the upper and lower uncertainty boundaries, but the value of $\operatorname{tr}_{\mathrm{T}}$ lay well within the uncertainty boundaries. Because subsurface temperature is more influenced by adjacent flux than is radon activity, the temperature-derived residence time (and flux) had less variation at the different testing points than $\operatorname{tr}_{\mathrm{Rn}}$, and therefore is proposed to be more representative than radon-derived flux and residence time.

The finding that values of $\operatorname{tr}_{\mathrm{T}}$ were shorter than $\operatorname{tr}_{\mathrm{Rn}}$ might be due to river water sampling of the radon activity at points with groundwater discharge. At these locations, radon activity is underestimated and subsequently the residence time is overestimated, and therefore appears to indicate longer residence time compared with temperature. The values of $\operatorname{tr}_{\mathrm{Rn}}$ were 1.12 orders of magnitude higher than $\operatorname{tr}_{\mathrm{T}}$, which could be due to the proximity of the testing points to the area where the $K_{v}$ is low. Ferguson and Bense (2011) have revealed that temperature-derived flux (and residence time) can provide up to two orders of magnitude variation from the actual advective flux when there are up to three orders of magnitude change in the values of $\mathrm{K}_{\mathrm{v}}$ in adjacent zones. Therefore, differences between $\operatorname{tr}_{\mathrm{T}}$ and $\operatorname{tr}_{\mathrm{Rn}}$ can be less than the differences between $\operatorname{tr}_{\mathrm{T}}$ and true advective dispersion flux. 


\section{Conclusion}

This study quantified the VHE and residence time using diel temperature variations and radon activity at different depths of the Ghezel-Ozan river sediment bed. The hydraulic conductivity of the sediment bed materials was also used, in the four divided zones of the study watershed,

5 to characterise the morphological features and their influence on the VHE pattern. At testing points with relatively lower altitude, downward flux occurred and the values of $\mathrm{K}_{\mathrm{v}}$ were lower compared with points at higher elevations where there was upward flux. This was affected by fine sediment particles which clogged the pore spaces of the stream bed sediment during downward movement. The values of diel temperature, radon activity and EC variations at the different depths revealed the highly dynamic characteristics of the subsurface flow, while the hyporheic exchange was mainly effected by larger scale regional subsurface flow.

Also, in this study, the results obtained from the PHAST model simulator were compared with the values of $\mathrm{VHE}_{\mathrm{T}}$ and $\mathrm{VHE}_{\mathrm{Rn}}$. The error analysis of the model output results indicated the highly acceptable performance of the PHAST model in estimating hyporheic vertical flux, due

to the low value of $|\varepsilon| /|\mathrm{VHD}|$. Furthermore, the spatial distribution map of downwelling and upwelling areas, as well as the magnitude of the hyporheic flux, was described by the PHAST model: downward flux was mainly observed in the central river sections, and upward flow mainly occurred along the river boundaries. The close correlation especially between VHEPHAST and $\mathrm{VHE}_{\mathrm{T}}\left(\mathrm{R}^{2}>0.95\right)$ indicated the high suitability of PHAST model to characterise hyporheic vertical flux.

The results of this study demonstrate that the meandering reaches can be considered as kinematic areas, as the hyporheic vertical flux in river curvatures that possess multiple sequences of riffle-pool points is extremely dynamic, and influenced by the river morphology and the pressure gradient between upstream and downstream. 


\section{Acknowledgment}

This study was financially funded by Zanjan's Natural Resources Office, Division of Water Resources Management (Grant Number: ZNWRM/21248-810/A2). I would like to express my gratitude to all of the laboratory staff, especially Mr Kambiz Amini from the Division of Water

5 Resource Management (Tarom region Branch) for their special assistance during sampling procedures.

\section{Figures Caption}

Figure1. Location of the study watershed (A); schematic diagram of the piezometer for calculation of $\mathrm{K}_{\mathrm{v}}$ and MLS for measurement of the streambed temperature at different depths.

10 Figure 2. Interpolated elevational contour map of the river bed sediments at the four study zones.

Figure 3. The principle component analysis between $\mathrm{K}_{\mathrm{v}}$ and sediment hydraulic and physical properties.

Figure 4. The magnitudes of temperature-derived VHE $\left(\mathrm{VHE}_{\mathrm{T}}\right)$ and radon-derived VHE

$15\left(\mathrm{VHE}_{\mathrm{Rn}}\right)$ at each testing point; negative values refer to the hyporheic upward flux and the positive values indicate downward flux in the hyporheic zone.

Figure 5. The magnitude of sediment bed radon activity (measured in situ at $1.05 \mathrm{~m}$ sediment depth) and the associated calculated residence time.

Figure 6. Diel temperature, radon activity and EC variations at different depths for Z1 and Z2; there are discrepancies between radon-derived and temperature-derived VHE.

Figure 7. Diel temperature, EC, and radon variations at different depths for Z3 and Z4 at the sampling points with the greatest discrepancy between $\mathrm{VHE}_{\mathrm{T}}$ and $\mathrm{VHE}_{\mathrm{Rn}}$. 
Figure 8. (A) Testing the PHAST model performance using plot of simulated vertical head residuals vs observed vertical head difference for the entire watershed, on the basis of running the calibrated model; the cyan area indicates where the error is higher than simulated results. (B) The summary of RSME and MAE for the four study zones, the spatial distribution of downwelling and upwelling locations, and the modelled VHE Comparison between $\mathrm{VHE}_{\text {PHAST }}$ with $\mathrm{VHE}_{\mathrm{T}}$ and $\mathrm{VHE}_{\mathrm{Rn}}$ and the subsequent magnitude of correlation coefficients $\left(\mathrm{R}^{2}\right)$.

Figure 9. (A) Relationship between $\operatorname{tr}_{\mathrm{Rn}}$ and $\operatorname{tr}_{\mathrm{T}}$; error bars indicate the $5^{\text {th }}$ and $95^{\text {th }}$ percentiles. (B) Radon-derived residence time $\left(\operatorname{tr}_{\mathrm{Rn}}\right)$. (C) Temperature-derived residence time $\left(\operatorname{tr}_{\mathrm{T}}\right)$. The lower and upper uncertainty boundaries at $95 \%$ confidence interval were obtained by Monte Carlo analysis.

\section{References}

Anibas, C., Buis, K., Verhoeven, R., Meire, P., and Batelaan, O.: A simple thermal mapping method for seasonal spatial patterns of groundwater-surface water interaction.

Anibas, C., Fleckenstein, J. H., Volze, N., Buis, K., Verhoeven, R., Meire, P., and Batelaan, O.: Transient or steady-state? Using vertical temperature profiles to quantify groundwater-surface water exchange. Hydrological Processes, 23(15), 2165-2177, 2009.

APHA. Methods for the Examination of Water and Wastewater. Washington, DC, 20 USA: American Public Health Association, American Water Works Association, Water Environment Federation, 23, 2005.

Arriaga, M. A., and Leap, D. I.: Using solver to determine vertical groundwater velocities by temperature variations, Purdue University, Indiana, USA. Hydrogeology Journal, 14(1-2), 253-263, 2006. 
Atkins, M. L., Santos, I. R., and Maher, D. T.: Assessing groundwater-surface water connectivity using radon and major ions prior to coal seam gas development (Richmond River Catchment, Australia). Applied Geochemistry, 73, 35-48.

doi:10.1016/j.apgeochem.2016.07.012, 2016. biogeomorphic succession and river channel morphodynamics. Journal of Geophysical Research: Earth Surface, 121(10), 1763-1785, 2016.

Boano, F., Harvey, J. W., Marion, A., Packman, A. I., Revelli, R., Ridolfi, L., and

Wörman, A.: Hyporheic flow and transport processes: Mechanisms, models, and

biogeochemical implications. Reviews of Geophysics, 52(4), 603-679, 2014.

Boano, F., Revelli, R., \& Ridolfi, L.: Modeling hyporheic exchange with unsteady stream discharge and bedform dynamics. Water Resources Research, 49(7), 4089-4099. doi: 10.1002/wrcr.20322, 2013.

Cardenas, M. B. : Stream-aquifer interactions and hyporheic exchange in gaining and losing sinuous streams. Water Resources Research, 45(6), 2009. 2000 
Chen, X., Dong, W., Ou, G., Wang, Z., and Liu, C.: Gaininbg and losing stream reaches have opposite hydraulic conductivity distribution patterns. Hydrology and Earth System Sciences, 17(7), 2569, 2013.

Constantz, J.: Heat as a tracer to determine streambed water exchanges. Water Resources Research, 44(4). doi: 10.1029/2008wr006996, 2008.

Cook, P., Lamontagne, S., Stieglitz, T., Cranswick, R., Hancock, G., and Shanafield, M.: A re-evaluation of groundwater discharge from the Burdekin Floodplain aquifer using geochemical tracers. NCGRT report, 2011.

Cook, P. G., and Herczeg, A. L.: Environmental tracers in subsurface hydrology:

10 Springer Science \& Business Media, 2012.

Cook, P. G., Stieglitz, T., and Clark, J. F.: Groundwater discharge from the Burdekin floodplain aquifer, North Queensland: CSIRO Land and Water, 2004.

Cranswick, R. H., Cook, P. G., and Lamontagne, S.: Hyporheic zone exchange fluxes and residence times inferred from riverbed temperature and radon data. Journal of Hydrology, 519, 1870-1881. doi:10.1016/j.jhydrol.2014.09.059, 2014.

Criswell, D. T.: Assessing irrigation-influenced groundwater flow and transport pathways along a reach of the Arkansas River in Colorado. Colorado State University, 2016.

Datry, T., Lamouroux, N., Thivin, G., Descloux, S., and Baudoin, J.: Estimation of sediment hydraulic conductivity in river reaches and its potential use to evaluate streambed clogging. River research and applications, 31(7), 880-891, 2015.

Deng, W., Balhoff, M., and Cardenas, M. B.: Influence of dynamic factors on nonwetting fluid snap-off in pores. Water Resources Research, 51(11), 9182-9189, 2015. 
Doherty, J.: PEST, Model-Independent Parameter Estimation User Manual. 705

Watermark Numerical Computing. Oxley, Australia, 2010.

Donath, F. M., Daughney, C. J., Morgenstern, U., Cameron, S. G., and Toews, M. W.: Hydrochemical interpretation of groundwater-surface water interactions at catchment and local scales, Lake Rotorua catchment, New Zealand. Journal of Hydrology, 54(1), 11, 2015.

Ferguson, G., and Bense, V.: Uncertainty in 1D Heat-Flow Analysis to Estimate Groundwater Discharge to a Stream. Ground Water, 49(3), 336-347. doi:10.1111/j.17456584.2010.00735, 2011.

Gariglio, F. P., Tonina, D., and Luce, C. H.: Spatiotemporal variability of hyporheic 7204, 2013.

Gomez-Velez, J. D., Harvey, J. W., Cardenas, M. B., and Kiel, B.: Denitrification in the Mississippi River network controlled by flow through river bedforms. Nature Geoscience, 8(12), 941-945, 2015. modelling study of hyporheic exchange pattern and the sequence, size, and spacing of stream bedforms in mountain stream networks, Oregon, USA. Hydrological Processes: An International Journal, 20(11), 2443-2457, 2009.

Gooseff, M. N.: Defining hyporheic zones-advancing our conceptual and operational definitions of where stream water and groundwater meet. Geography Compass, 4(8), 945-

$955,2010$. 
Hatch, C. E., Fisher, A. T., Revenaugh, J. S., Constantz, J., and Ruehl, C.:

Quantifying surface water-groundwater interactions using time series analysis of streambed thermal records: Method development. Water Resources Research, 42(10), 2006.

Hiatt, M., and Passalacqua, P.: Hydrological connectivity in river deltas: The firstorder importance of channel-island exchange. Water Resources Research, 51(4), 2264-2282, 2015.

Hounslow, A. (1995). Water quality data: analysis and interpretation: CRC press.

Hyun, Y., Kim, H., Lee, S.-S., and Lee, K.-K.: Characterizing streambed water fluxes using temperature and head data on multiple spatial scales in Munsan stream, South Korea. Journal of Hydrology, 402(3), 377-387, 1995.

Irvine, D. J., Cranswick, R. H., Simmons, C. T., Shanafield, M. A., and Lautz, L. K.: (2015). The effect of streambed heterogeneity on groundwater-surface water exchange fluxes inferred from temperature time series. Water Resources Research, 51(1), 198-212, 2015.

Jiang, W., Song, J., Zhang, J., Wang, Y., Zhang, N., Zhang, X., Yang, X.: Spatial variability of streambed vertical hydraulic conductivity and its relation to distinctive stream morphologies in the Beiluo River, Shaanxi Province, China. Hydrogeology Journal, 23(7), $1617,2015$.

Jorda, H., Bechtold, M., Jarvis, N., and Koestel, J.: Using boosted regression trees to explore key factors controlling saturated and near-saturated hydraulic conductivity. European Journal of Soil Science, 66(4), 744-756, 2015.

Kasahara, T., and Wondzell, S. M.: Geomorphic controls on hyporheic exchange flow in mountain streams. Water Resources Research, 39(1), SBH 3-1. doi:10.1029/2002WR001386, 2003. 
Käser, D. H., Binley, A., Krause, S., and Heathwaite, A. L.: Prospective modelling of 3D hyporheic exchange based on high-resolution topography and stream elevation. Hydrological Processes, 28(4), 2579-2594, 2014.

Kennedy, C. D., Genereux, D. P., Corbett, D. R., and Mitasova, H.: Spatial and temporal dynamics of coupled groundwater and nitrogen fluxes through a streambed in an agricultural watershed. Water Resources Research, 45(9), 2009.

Lambs, L.: Interactions between groundwater and surface water at river banks and the confluence of rivers. Journal of Hydrology, 288(3), 312-326, 2004.

Lamontagne, S., Taylor, A., Cook, P., and Hamilton, S.: Interconnection of surface and groundwater systems-river losses from losing/disconnected streams. Macquarie River site report: CSIRO: Water for a Healthy Country National Research Flagship, Adelaide, 2011.

Lapham, W. W.: Use of temperature profiles beneath streams to determine rates of vertical ground-water flow and vertical hydraulic conductivity. Retrieved from, 1989.

Leaney, F. W., and Herczeg, A. L.: A rapid field extraction method for determination 15 of radon-222 in natural waters by liquid scintillation counting. Limnology and Oceanography: Methods, 4(7), 254-259. doi:10.4319/lom.2006.4.254, 2006.

Lunardini, V. J.: Heat transfer in cold climates: Van Nostrand Reinhold Company, 1981.

McCallum, J. L., Cook, P. G., Brunner, P., and Berhane, D.: Solute dynamics during bank storage flows and implications for chemical base flow separation. Water Resources Research, 46(7). doi:10.1029/2009WR008539, 2010. 
Meghdadi, A., and Eyvazi, M.: Multi-level qualification of Parafluvial Exchange within the Hyporheic Zone Affected by River Sinuosity and Seasonal Change using Multitracer Methods. Hydrology and Earth System Science, 374, 58-78, 2017.

Meghdadi, A., and Javar, N.: Quantification of spatial and seasonal variations in the proportional contribution of nitrate sources using a multi-isotope approach and Bayesian isotope mixing model. Environmental Pollution, 235, 207-222, 2018.

Naranjo, R. C., Pohll, G., Niswonger, R. G., Stone, M., and Mckay, A.: Using heat as a tracer to estimate spatially distributed mean residence times in the hyporheic zone of a riffle-pool sequence. Water Resources Research, 49(6), 3697-3711, 2013. storage modeling using temperature and solute data with multiobjective calibration: 2 . Temperature and solute. Water Resources Research, 46(12). doi: 10.1029/2009wr008759, 2010.

Parkhurst, D. L., Kipp, K. L., and Charlton, S. R .: PHAST Version 2-A program for simulating groundwater flow, solute transport, and multicomponent geochemical reactions. In Interior, U. d. o. (Ed.), Modeling Techniques (Vol. 13): US Geological Survey, 2010.

Riley, J. D., and Rhoads, B. L.: Flow structure and channel morphology at a natural confluent meander bend. Geomorphology, 163, 84-98, 2012.

Riley, J. D., Rhoads, B. L., Parsons, D. R., and Johnson, K. K.: Influence of junction angle on three-dimensional flow structure and bed morphology at confluent meander bends during different hydrological conditions. Earth Surface Processes and Landforms, 40(2), 252$271,2015$. 
Schornberg, C., Schmidt, C., Kalbus, E., and Fleckenstein, J. H.: Simulating the effects of geologic heterogeneity and transient boundary conditions on streambed temperatures - Implications for temperature-based water flux calculations. Advances in Water Resources, 33(11), 1309-1319, 2010. the vertical hyporheic water exchange effected by hydraulic conductivity and river morphology at a natural confluent meander bend. Hydrological Processes, 2017.

Stewardson, M., Datry, T., Lamouroux, N., Pella, H., Thommeret, N., Valette, L., and Grant, S.: Variation in reach-scale hydraulic conductivity of streambeds. Geomorphology, 259, 70-80, 2016.

Tonina, D.: Interaction: The hyporheic exchange. Fluid Mechanics of Environmental Interfaces, 255, 2012.

Waples, D. W., and Waples, J. S.: A Review and Evaluation of Specific Heat Capacities of Rocks, Minerals, and Subsurface Fluids. Part 2: Fluids and Porous Rocks.

15 Natural Resources Research, 13(2), 123-130. doi:10.1023/b:narr.0000032648.15016.49, 2004.

Winston, R. B.: ModelMuse: a graphical user interface for MODFLOW-2005 and PHAST: US Geological Survey Reston, VA, 2009.

Wondzell, S. M., LaNier, J., and Haggerty, R., Evaluation of alternative groundwater 
Xian, Y., Jin, M., Liu, Y., and Si, A.: Impact of lateral flow on the transition from connected to disconnected stream-aquifer systems. Journal of Hydrology, 548, 353-367. doi:10.1016/j.jhydrol.2017.03.011, 2017.

Zhang, G., Song, J., Wen, M., Zhang, J., Jiang, W., Wang, L., Wang, Y.: Effect of bank

5 curvatures on hyporheic water exchange at meter scale. Hydrology Research, 48(2), 3, 2017.

\section{Tables}

Table 1. The stream bed sediment grain size distribution at the four study zones

\begin{tabular}{|l|l|l|l|ll|}
\hline & $\mathrm{Z} 1$ & $\mathrm{Z} 2$ & $\mathrm{Z3}$ & $\mathrm{Z} 4$ & \\
\hline$<0.075$ mm cumulative weight & 23.2 & 26.5 & 17.8 & $19.4 \quad 10$ \\
\hline$<2$ mm cumulative weight & 75.6 & 74.2 & 81.7 & 80.4 \\
\hline $\mathrm{D}_{50}$ & 0.94 & 0.87 & 1.21 & 1.1 \\
\hline Coefficient of uniformity (f) & 1.84 & 2.87 & 2.04 & 2.41 \\
\hline Porosity & 0.43 & 0.40 & 0.42 & 0.41 \\
\hline
\end{tabular}

Table 2. Statistical analysis of VHET and VHERn and stream sediment bed vertical hydraulic conductivity. The negative and positive VHE values refer to upward and downward flux, respectively, the magnitudes of the mean and standard deviation were calculated based on the absolute values of VHET and VHERn.

\begin{tabular}{|c|c|c|c|c|c|c|}
\hline $\begin{array}{c}\text { Study } \\
\text { segment }\end{array}$ & $\begin{array}{c}\text { Test } \\
\text { point }\end{array}$ & Parameter & Range & $\begin{array}{l}\text { Standard } \\
\text { deviation }\end{array}$ & $\begin{array}{l}\text { Coefficient } \\
\text { of variation }\end{array}$ & Mean \\
\hline $\mathrm{Z1}$ & $\begin{array}{l}\text { B1 to } \\
\text { B12 }\end{array}$ & $\begin{array}{l}\mathrm{Kv} \text { (m/day) } \\
\text { VHE Rn (m/day) } \\
\text { VHE T (m/day) }\end{array}$ & $\begin{array}{l}0.49 \text { to } 2.82 \\
1.22 \text { to }-1.32 \\
1.04 \text { to }-1.05\end{array}$ & $\begin{array}{l}0.739 \\
0.368 \\
0.294 \\
\end{array}$ & $\begin{array}{l}0.511 \\
0.554 \\
0.442\end{array}$ & $\begin{array}{l}1.445 \\
0.664 \\
0.665\end{array}$ \\
\hline $\mathrm{Z} 2$ & $\begin{array}{c}\text { B13 to } \\
\text { B21 }\end{array}$ & $\begin{array}{l}\text { Kv (m/day) } \\
\text { VHE Rn (m/day) } \\
\text { VHE T (m/day) }\end{array}$ & $\begin{array}{c}0.27 \text { to } 2.07 \\
0.26 \text { to }-1.55 \\
1.8 \text { to }-.98\end{array}$ & $\begin{array}{l}0.614 \\
0.555 \\
0.506\end{array}$ & $\begin{array}{l}0.560 \\
1.226 \\
0.730\end{array}$ & $\begin{array}{l}1.096 \\
0.680 \\
0.693\end{array}$ \\
\hline $\mathrm{Z3}$ & $\begin{array}{l}\text { B22 to } \\
\text { B27 }\end{array}$ & $\begin{array}{l}\text { Kv (m/day) } \\
\text { VHE Rn (m/day) } \\
\text { VHE T (m/day) }\end{array}$ & $\begin{array}{c}0.64 \text { to } 3.76 \\
0.55 \text { to }-.9 \\
1.04 \text { to }-1.08\end{array}$ & $\begin{array}{l}1.333 \\
0.216 \\
0.234\end{array}$ & $\begin{array}{l}0.699 \\
0.372 \\
0.305\end{array}$ & $\begin{array}{l}1.907 \\
0.582 \\
0.767\end{array}$ \\
\hline $\mathrm{Z4}$ & $\begin{array}{c}\text { B28 to } \\
\text { B33 }\end{array}$ & $\begin{array}{l}\text { Kv (m/day) } \\
\text { VHE Rn (m/day) } \\
\text { VHE T (m/day) }\end{array}$ & $\begin{array}{l}0.61 \text { to } 2.425 \\
0.64 \text { to }-1.15 \\
1.08 \text { to }-0.78\end{array}$ & $\begin{array}{l}0.648 \\
0.294 \\
0.199\end{array}$ & $\begin{array}{l}0.456 \\
0.453 \\
0.270\end{array}$ & $\begin{array}{l}1.421 \\
0.647 \\
0.736\end{array}$ \\
\hline
\end{tabular}


https://doi.org/10.5194/hess-2019-446

Preprint. Discussion started: 2 October 2019

(c) Author(s) 2019. CC BY 4.0 License.
Hydrology and Earth System Sciences Discussions

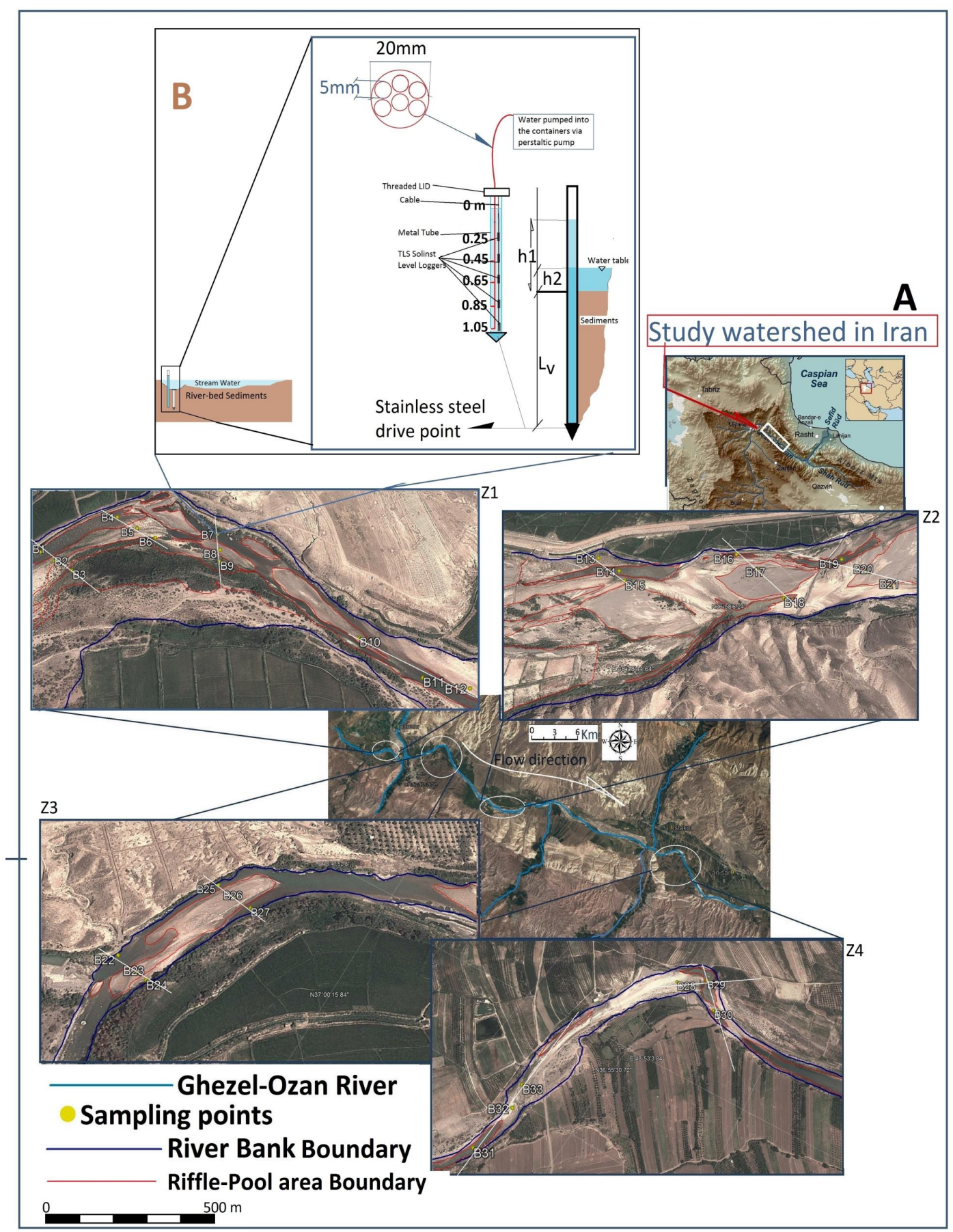

Figure1. Location of the study watershed (A); schematic diagram of the piezometer for calculation of KV and MLS for measurement of the streambed temperature at different depths (the scale bar at the bottom of the figure refers to Z1 to Z4). 
https://doi.org/10.5194/hess-2019-446

Hydrology and

Preprint. Discussion started: 2 October 2019

(c) Author(s) 2019. CC BY 4.0 License.
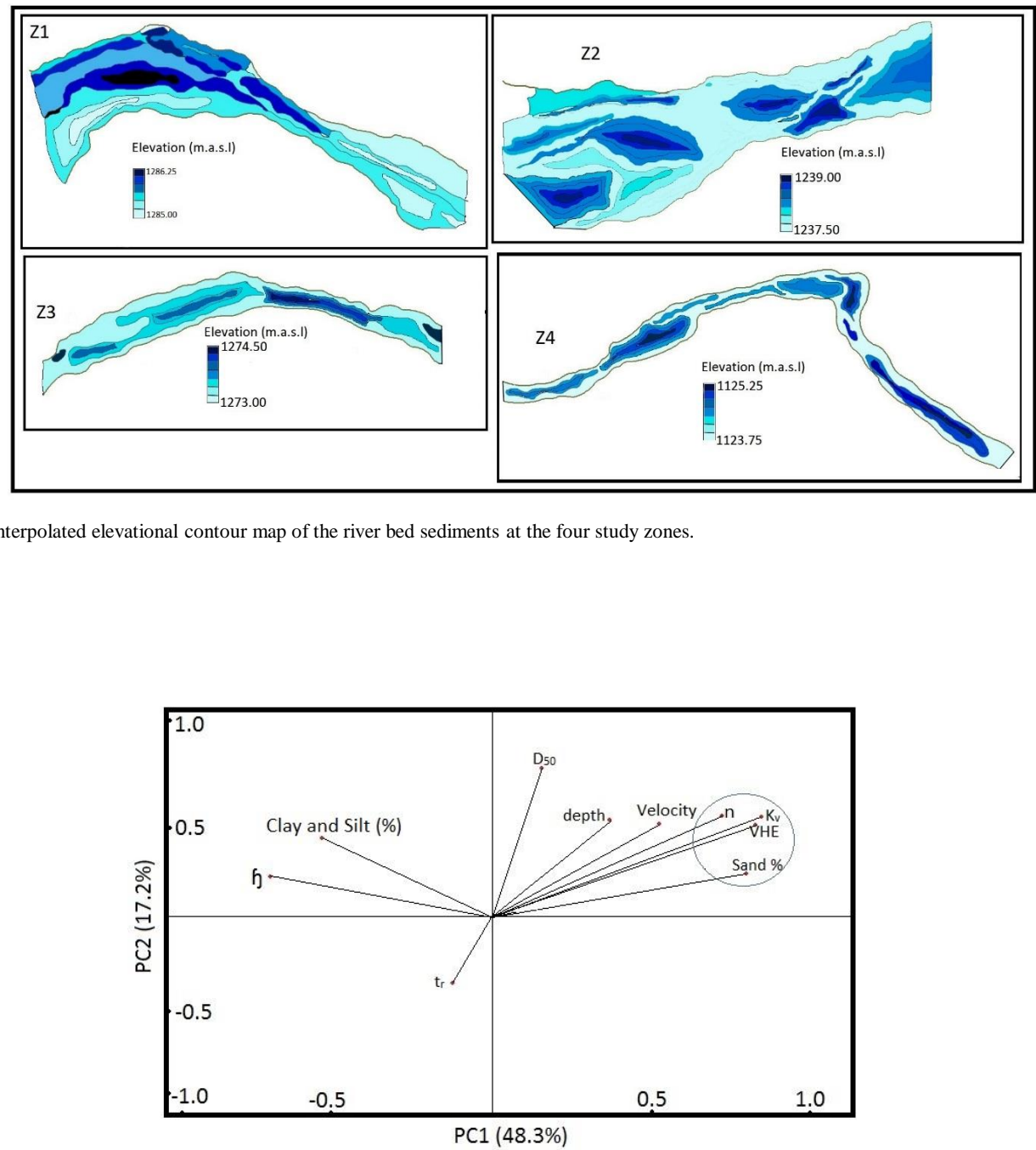

Figure 3. The principle component analysis between $\mathrm{K}_{\mathrm{v}}$ and sediment hydraulic and physical properties. 


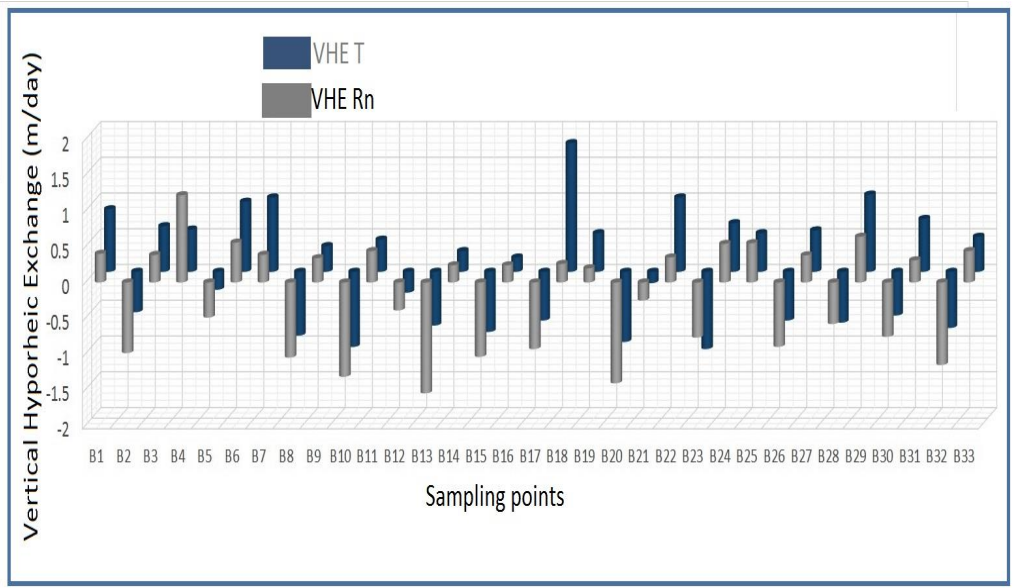

Figure 4. The magnitudes of temperature-derived $\mathrm{VHE}\left(\mathrm{VHE}_{\mathrm{T}}\right)$ and radon-derived $\mathrm{VHE}\left(\mathrm{VHE}_{\mathrm{Rn}}\right)$ at each testing point; negative values refer to the hyporheic upward flux and the positive values indicate downward flux in the hyporheic zone.

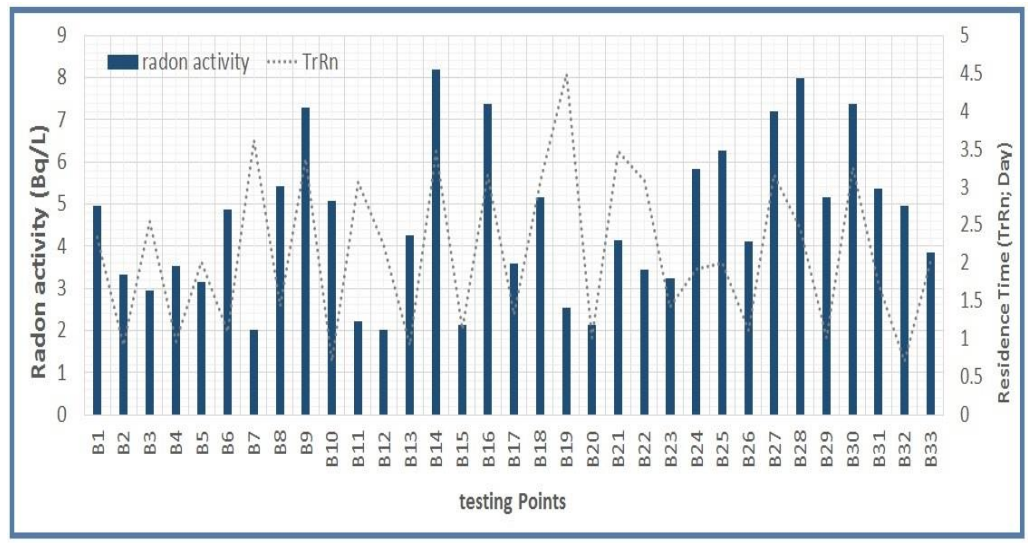

Figure 5. The magnitude of sediment bed radon activity (measured in situ at $1.05 \mathrm{~m}$ sediment depth) and the associated calculated residence time. 

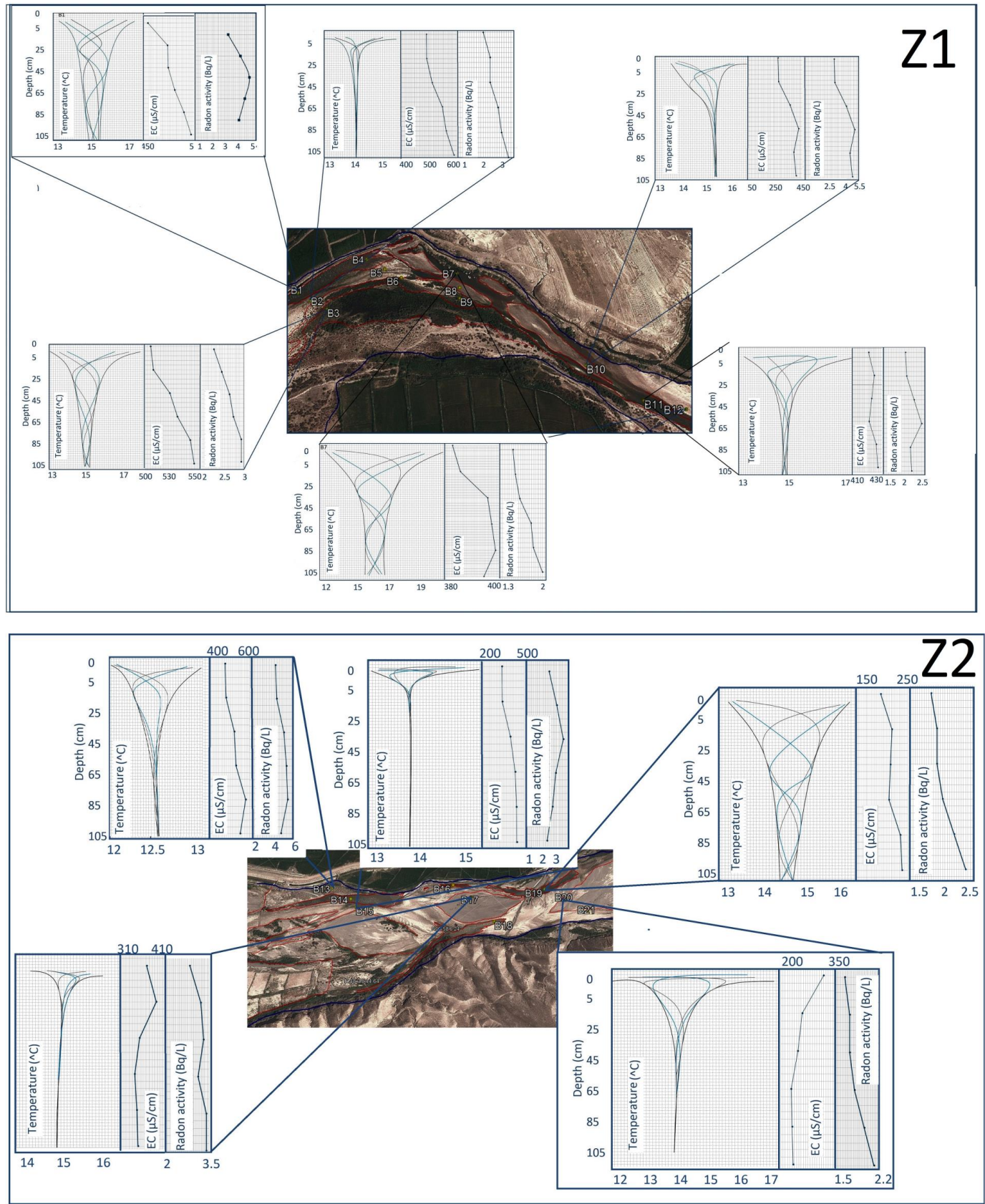

Figure 6. Diel temperature, radon activity and EC variations at different depths for Z1 and Z2; there are discrepancies between radon-derived and temperature-derived VHE. 


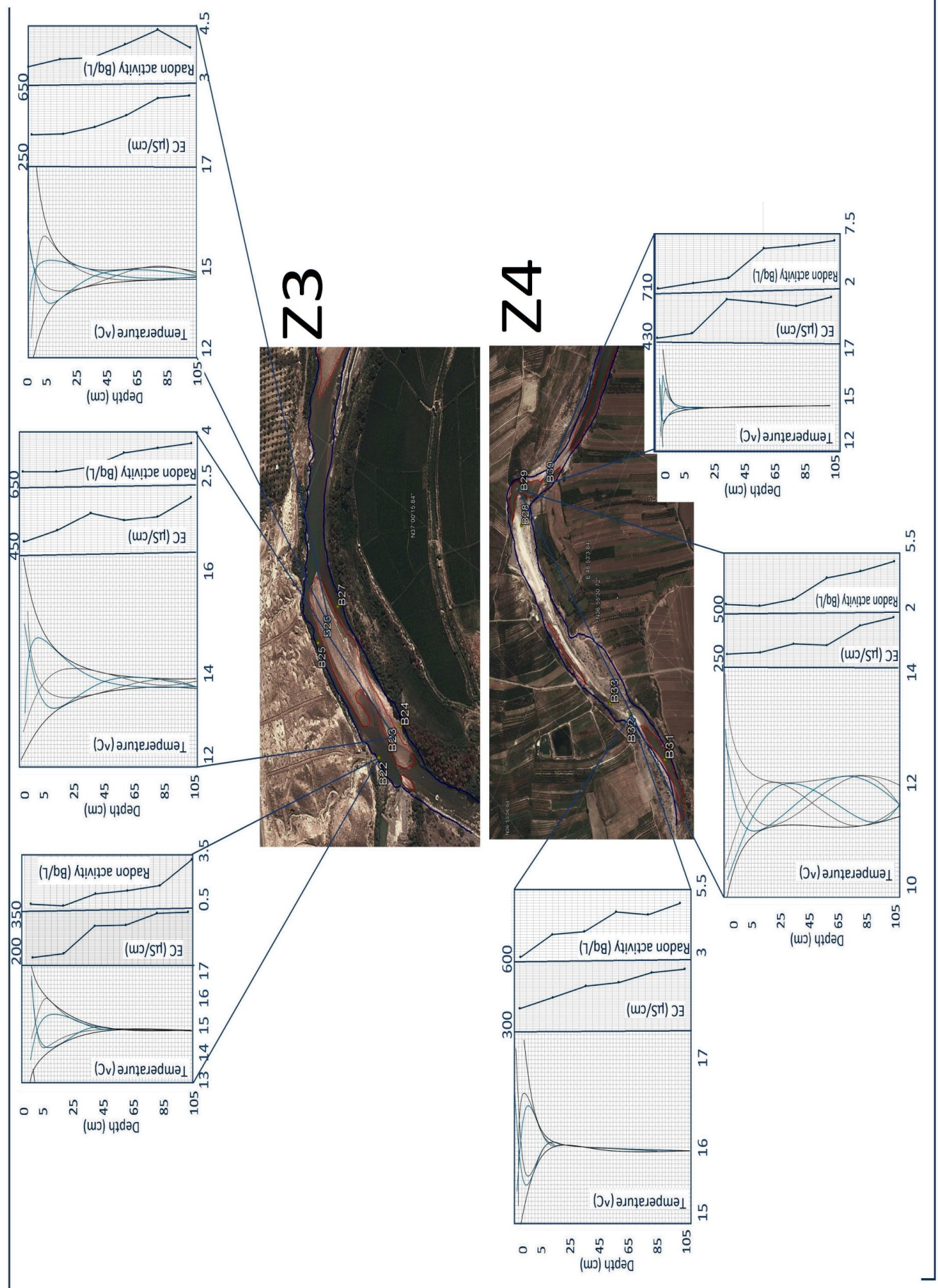




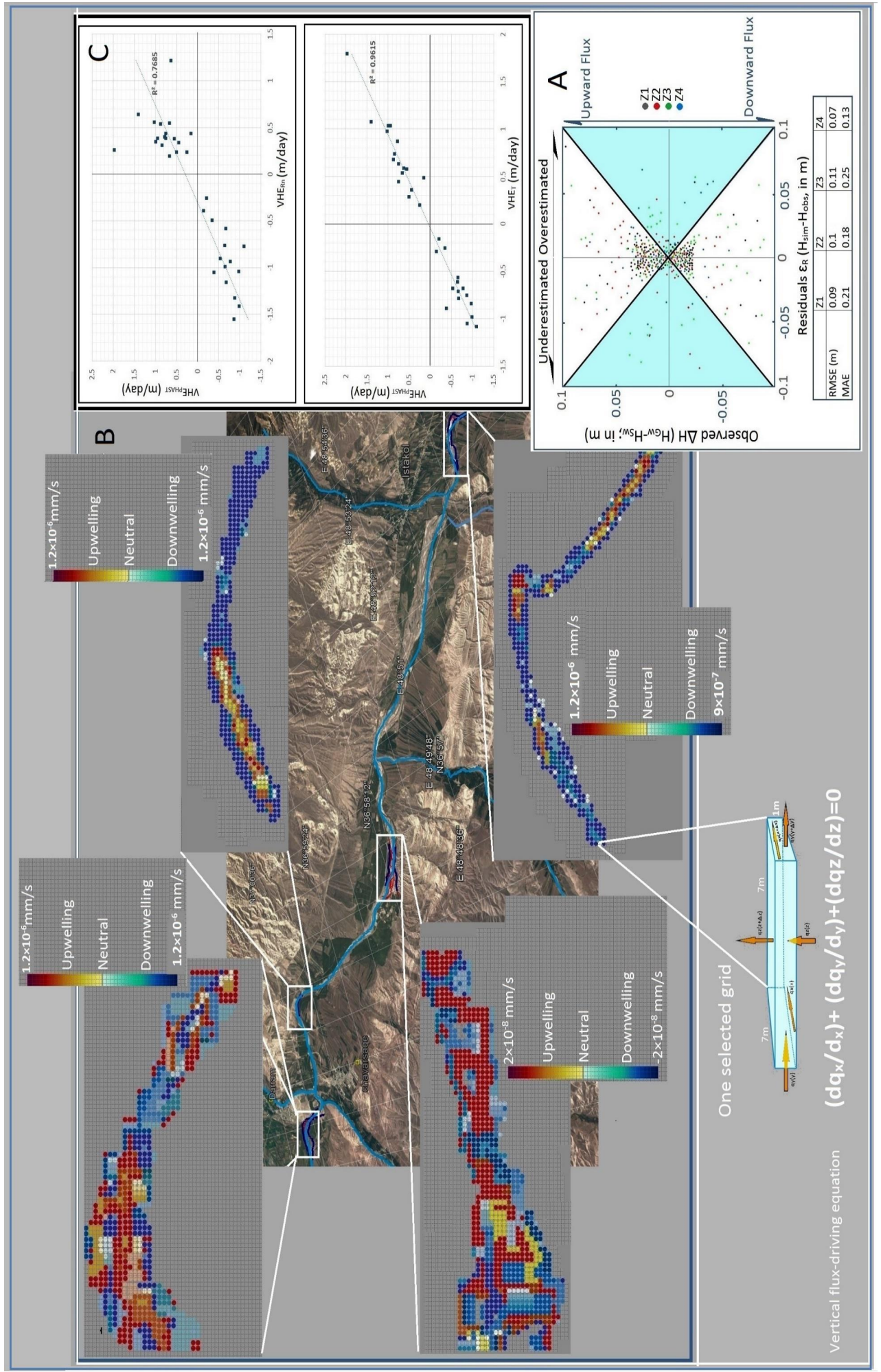

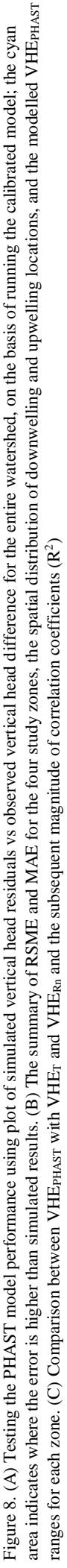




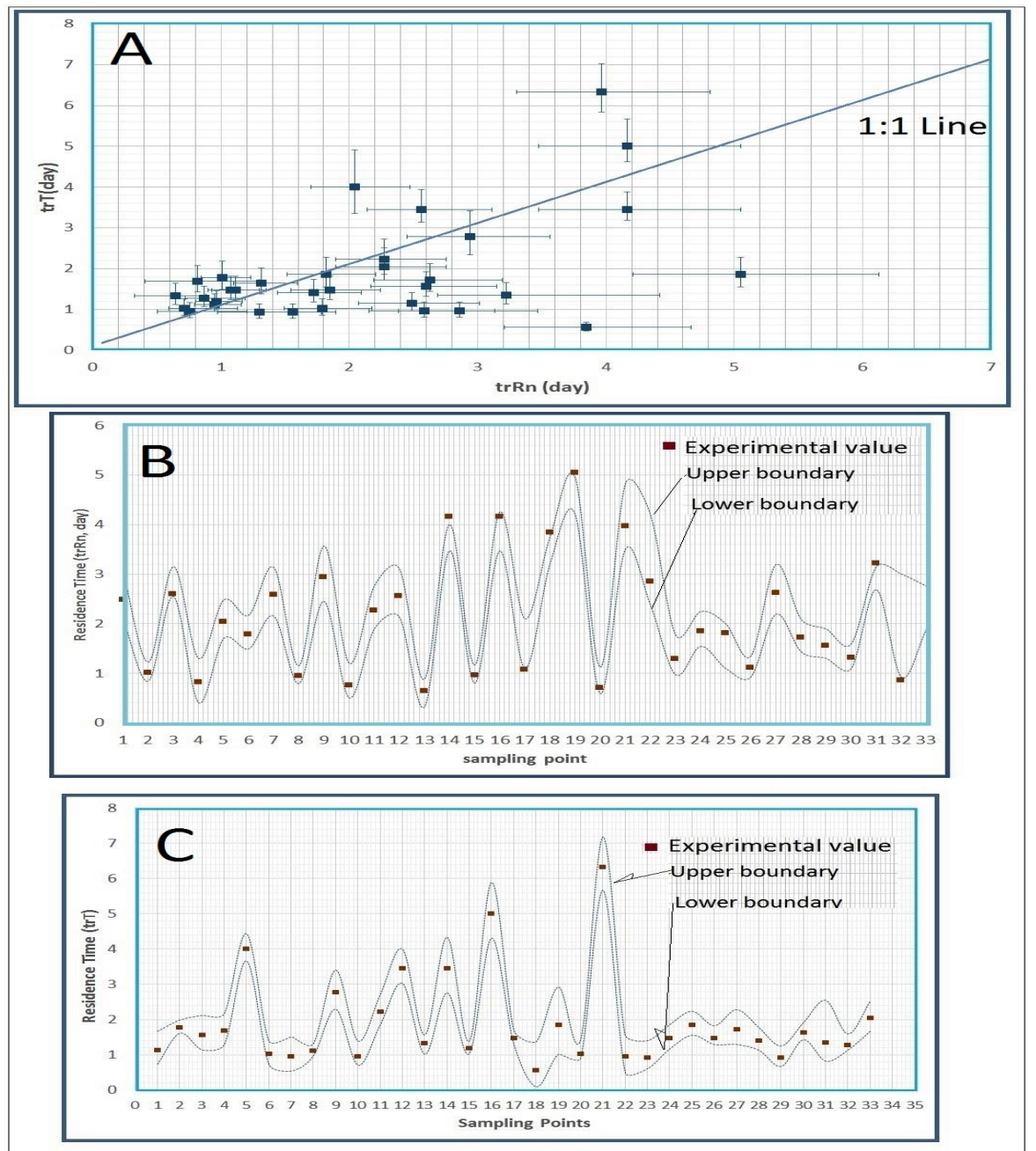

Figure 9. (A) Relationship between $\operatorname{tr}_{\mathrm{Rn}}$ and $\operatorname{tr}_{\mathrm{T}}$; error bars indicate the $5^{\text {th }}$ and $95^{\text {th }}$ percentiles. (B) Radon-derived residence time $\left(\operatorname{tr}_{\mathrm{Rn}}\right)$. $(\mathrm{C})$ Temperature-derived residence time $\left(\operatorname{tr}_{\mathrm{T}}\right)$. The lower and upper uncertainty boundaries at $95 \%$ confidence interval were obtained by Monte Carlo analysis. 